\title{
ESCHERICHIA COLI, OTHER COLIFORM, AND ENVIRONMENTAL CHEMOHETEROTROPHIC BACTERIA IN ISOLATED WATER POOLS FROM SIX CAVES IN NORTHERN ALABAMA AND NORTHWESTERN GEORGIA
}

\author{
Joshua W. Campbell ${ }^{1}$, Anna Watson ${ }^{1}$, Cindy Watson ${ }^{2}$, Hannah Ball ${ }^{1}$, And Richard Pirkle ${ }^{1}$
}

\begin{abstract}
Escherichia coli and other bacteria can be used as indicators of water quality within a cave ecosystem. However, bacterial species within caves have not been thoroughly documented, especially in the southeastern United States. Water from isolated pools was gathered along transects from six caves in northern Alabama and northwestern Georgia. We used cultivation techniques to isolate and characterize bacteria. Diversity of coliforms and some environmental genera were determined for each cave, and abundance was determined for E. coli and other coliforms. Distance from the entrance in most caves did not statistically correlate with abundance or species richness of bacteria. A total of fifty bacterial species and one fungal species were isolated from the six caves, with over half of these species considered potentially pathogenic in humans. Some species isolated, such as Vibrio alginolyticus and $V$. fluvialis, are considered primarily marine and are not expected isolates of cave waters. Most of the species we isolated have never been reported from limestone cave ecosystems. Overall, coliforms were found in all tested caves, indicating fecal contamination of all six caves.
\end{abstract}

\section{INTRODUCTION}

Microbial communities in caves are poorly understood (Groth and Saiz-Jimenez, 1999), but caves do support a complex microbial life (Northup and Lavoie, 2001; Caumartin, 1963). Caves contain unique populations that rely on both chemoautotrophic and heterotrophic interactions for survival. Many bacteria in caves are considered non-native species that have been transported into a cave via water, air, or animals (Northup and Lavoie, 2001), and how these bacteria interact and compete with endemic microflora is unknown. Alabama and Georgia are caverich states (Culver et al., 2006) that offer opportunities for microbial studies. Most caves in these two states are found in the Appalachian Plateaus and Interior Low Plateaus physiographic provinces and are formed in fossiliferous Paleozoic limestone. Despite its having a high density of caves, there is a scarcity of literature for this region concerning cave bacteria.

Most caves are considered to be nutrient (carbon) limited (Poulson and White, 1969; Culver, 1970), and caveinhabiting organisms may be constrained by these limitations (Peck, 1976; Taylor et al., 2005). By breaking down organic matter and recycling nutrients, heterotrophic bacteria are important components of a cave ecosystem. Most bacterial communities in caves depend, like other heterotrophs, on allochthonous sources of organic matter (Laiz et al., 2000). However, large increases of bacteria in cave waters, associated with increased organic matter, can rob the waters of dissolved oxygen, which could cause massive changes in community structure of invertebrates and other organisms (Graening and Brown, 2003).

Coliform bacteria (Enterobacteriacae) are gram-negative, aerobic and facultatively anaerobic, rod-shaped bacteria that ferment lactose to produce acid. They produce $\beta$-galactosidase within 48 hours at $35^{\circ} \mathrm{C}$ (Clesceri et al., 1998). Some coliforms are found in soil or vegetation, whereas fecal coliform are bacteria that usually live in the intestines of warm-blooded animals, making them a useful indicator of fecal contamination. Outside the intestines of warm-blooded animals, fecal coliform bacteria can survive for extended time periods. In karst aquifers, $E$. coli and other fecal coliform bacteria can remain viable for several months in water and stream sediments (Davis et al., 2005) and can be transported several kilometers in karst aquifers (Green et al., 1990). Lower temperatures found in cave environments reduce bacterial metabolism and increase their life span, allowing them to survive in these less-than-optimum conditions (Davis et al., 2005).

Coliform bacteria can be indicators for potential pathogens responsible for various waterborne diseases (Hunter et al., 2004) or be pathogens themselves, such as certain strains of $E$. coli. Coliform contamination can occur in caves (e.g. Lerch et al., 2001; Hunter et al., 2004; Kelly et al., 2009), with probable sources being the

\footnotetext{
${ }^{1}$ Shorter College, School of Sciences and Mathematics, 315 Shorter Avenue, Rome, GA, 30165, USA

${ }^{2}$ Veterinary Diagnostic and Investigational Laboratory, College of Veterinary Medicine, University of Georgia, Tifton, GA 31793, USA
} 


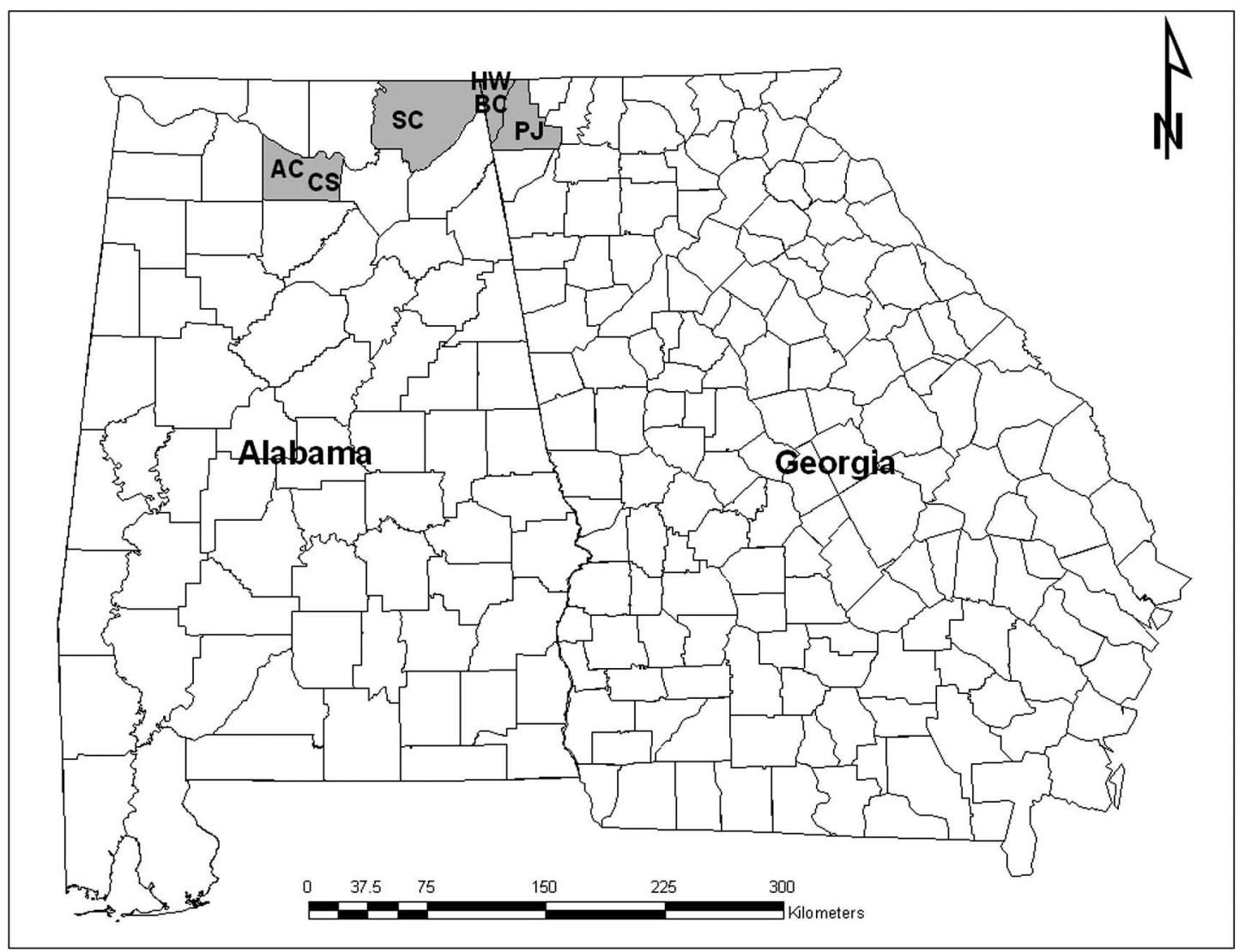

Figure 1. Approximate locations of the six caves in our study. $\mathrm{AC}=$ Anvil Cave, $\mathrm{BC}=\mathrm{Byers}$ Cave, $\mathrm{CS}=\mathrm{Cave}$ Springs Cave, HW=Howard's Waterfall Cave, $\mathbf{P J}=$ Pettyjohns Cave, $\mathbf{S C}=$ Sauta Cave. Counties in which these caves are located have been shaded.

watershed or animals that excrete waste products within the cave. Coliform and environmental bacteria can enter a cave by water that drains into a cave from the watershed (Lerch et al., 2001; Kelly et al., 2009), primarily from a stream flowing directly into a cave or by seepage through soil or rock. Bats and other animals can also be major contributors of coliforms by excreting waste products within a cave ecosystem. Human visitors are another possible source of coliform bacteria within a cave ecosystem. Humans can bring bacteria into caves on the soles of their shoes and by dumping feces (Hunter et al., 2004). Some English caves showed contamination of certain bacterial species after cavers passed through (Moore and Sullivan, 1997, p. 80). Northup et al. (1997) found that cave areas frequently traversed by humans contained more bacterial species than less-frequented areas. Therefore, the recreational use of caves and human-induced land-use changes could lead to increases in coliform bacteria to levels considered a public health threat, while also affecting the natural bacterial assemblages in ways that are not yet understood.

In this study we tested water pools in six caves from northern Alabama and northwestern Georgia for abundance and species richness of coliform and other environ- mental bacteria. We hypothesized that caves with more human or animal visitors or in a watershed with agricultural or sewage runoff would have higher bacterial abundance and species richness. We also hypothesized that abundance of coliforms and other bacteria would be greater closer to the entrance.

\section{Methods}

\section{STUdy Sites}

Between January and July 2008, water samples were gathered and tested from six caves in northern Alabama (Anvil and Cave Springs Caves, Morgan Country; Sauta Cave, Jackson County) and northwestern Georgia (Byers and Howard's Waterfall Cave, Dade County; Pettyjohns Cave, Walker County) (Fig. 1). These six caves were chosen due to their length and accessibility, the presence of pools, and the different numbers of human and animal visitors at the caves. All of our collection sites are in horizontal caves in fossiliferous limestone.

\section{SAmpling Procedure}

Within each cave we aseptically took water samples from locations three or four different distances from the 
entrance. At each location we took two $100 \mathrm{ml}$ samples, generally from each of five cave pools. The pools had surface areas of $100 \mathrm{~cm}^{2}$ to $1000 \mathrm{~cm}^{2}$ and were separated by at least 1 meter. To avoid spikes of re-suspended bacteria from soil during storms, selected cave pools were not connected to any stream or runoff area and appeared to be supplied primarily by dripping stalactites. The selected pools rarely, if ever, become dry. Sauta and Cave Springs Caves contain streams that flow from their entrances. If isolated cave pools could not be found, stagnant areas of the creeks were sampled.

One water sample from each cave pool was stored at 2 to $4{ }^{\circ} \mathrm{C}$ for future cultures, and a second undiluted sample was poured and sealed into a Colisure quanti-tray (IDEXX Laboratories, Inc.) and placed in an incubator at $35^{\circ} \mathrm{C}$ for up to 48 hours. Enzyme-based methods are widely accepted as a standard for detecting $E$. coli and other coliforms in water (Olstadt et al., 2007). Colisure products are approved by the Environmental Protection Agency for testing of drinking water and groundwater for total coliform bacteria and $E$. coli and are able to detect $E$. coli and other coliforms at one organism (up to 2419.6) per $100 \mathrm{ml}$ (U.S. EPA, 1994; U.S. EPA, 1997; U.S. EPA, 1999, p. V-12-V-13). Coliforms produce the enzyme $\beta$-galactosidase, which is detected by cleaving Colisure's nutrient-indicator CPRG (chlorophenol red $\beta$-D-galactopranoside). The cleaving causes the water sample to change color over a 24 to 48 hour period from yellow to red or magenta, and $E$. coli causes the sample to fluoresce green when exposed to UV light because $E$. coli metabolizes the nutrient indicator MUG (4-methyllumbelliferyl b-D-glucuronide). Colisure products detect E. coli and other coliforms with high confidence and suppress the growth of galactosidase-producing non-coliform organisms, thus resulting in a low rate of false positives (Olstadt et al., 2007). Our abundance tests are presumptive, but we did culture $E$. coli from all water samples, thus confirming the presence of $E$. coli.

\section{Bacterial Identification Procedure}

A subsample $(10 \mu \mathrm{l})$ of the water that had been stored at 2 to $4{ }^{\circ} \mathrm{C}$ was plated on MacConkey agar, a selective and differential plating medium used for isolating and differentiating lactose-fermenting from non-lactose fermenting gram-negative bacteria (BBL MacConkey II Agar). The cultures were incubated at $37{ }^{\circ} \mathrm{C}$ for $\sim 48$ hours. If no growth was present after 48 hours, pool water $(10 \mu \mathrm{l})$ was inoculated into tryptic soy broth, incubated overnight and then plated back onto MacConkey agar. Any bacterial colonies that appeared morphologically (color, shape, or size) different were transferred to tryptic soy agar with 5\% sheep blood. Qualitative oxidase and indole tests were completed using BBL DrySlide products. Bacteria that were oxidase negative and indole positive were again streaked on MacConkey and Simmon's Citrate media. MacConkey plates that were lactose positive with a strong precipitate around the colony and Simmon's Citrate negative were determined to be E. coli. If MacConkey plates were lactose + with no precipitate or lactose - and the Simmon's Citrate was + or - , the bacteria were placed on a Trek Sensititre System GN ID Panel. A 0.5 McFarland suspension of the isolate was prepared in sterile distilled water and inoculated into the GN ID Panel. If a bacteria was not identified by the Trek Sensititre System, the bacteria was placed on a Bio Merieux API 20E or Remel Rap ID NF+ System for identification. All procedures followed standard methods (Clesceri et al., 1998).

Abundance and species richness data were analyzed with GLM (Statistix 9 program, Analytical Software, Tallahassee, Florida) to conduct one-way ANOVAs with distance intervals as the independent variable and coliform bacteria and E. coli abundances and total number of bacterial species cultured as dependent variables. The Tukey's multiple comparison procedure in the same program was used to determine differences in relative abundances of $E$. coli and other coliform bacteria and bacterial species among caves. Due to differences in location and number of water pools among caves, locations were assigned to three zones, the entrance zone $0-75 \mathrm{~m}$, the intermediate zone $75-125 \mathrm{~m}$, and the deep zone $>125 \mathrm{~m}$, for 166 bacterial abundances and species richness analysis.

\section{RESULTS}

We collected ten coliform and forty environmental bacterial species from the six caves, with at least twentyseven of these species considered to be potentially pathogenic. Most bacterial species were isolated from Pettyjohns Cave, followed by Sauta and Cave Spring Caves (Table 1). There was little consistency in species occurrence between caves, with thirty-three species isolated from only one cave (Table 1). E. coli was the only species isolated from all caves. Cave Springs Cave had significantly higher E. coli and other coliform abundance compared to all other caves except Sauta Cave (Fig. 2). Neither species richness $(P=0.8102)$ or abundance $(P=0.2572)$ of $E$. coli and other coliform were significantly different among distance intervals when 163 data from all caves were pooled into different zones. However, many differences were detected between various distance zones within individual caves (Table 2). Because we did not dilute our water samples, some of our bacteria abundance numbers are conservative. Due to the heterogeneity and availability of water pools within caves, results will be discussed separately for each cave. The forty environmental bacteria species were not targeted and considered incidental in our cultures. Therefore, our species richness numbers do not reflect the true species richness of each cave.

\section{Anvil Cave}

E. coli and other coliform bacteria were significantly higher within the entrance zone compared to all other 
Table 1. Bacteria species isolated from six caves located in North Alabama and Northwest Georgia. Escherichia coli is the only species cultivated from all caves.

\begin{tabular}{|c|c|c|c|c|c|c|}
\hline Bacteria Species & $\begin{array}{l}\text { Anvil } \\
\text { Cave }\end{array}$ & $\begin{array}{l}\text { Byers } \\
\text { Cave }\end{array}$ & $\begin{array}{c}\text { Cave } \\
\text { Springs }\end{array}$ & $\begin{array}{l}\text { Howard's } \\
\text { Waterfall }\end{array}$ & $\begin{array}{c}\text { Pettyjohns } \\
\text { Cave }\end{array}$ & $\begin{array}{l}\text { Sauta } \\
\text { Cave }\end{array}$ \\
\hline \multicolumn{7}{|l|}{ Coliform Bacteria } \\
\hline Citrobacter freundii & $\mathrm{X}$ & & & & $\mathrm{X}$ & $\mathrm{X}$ \\
\hline Enterobacter amnigenus & $\mathrm{X}$ & & & & & \\
\hline Enterobacter cancerogenus & & & & $\mathrm{X}$ & $\mathrm{X}$ & \\
\hline Enterobacter intermedius & $\mathrm{X}$ & & & & & \\
\hline Enterobacter $s p$. & $\mathrm{X}$ & & & & $\mathrm{X}$ & \\
\hline Escherichia coli & $\mathrm{X}$ & $\mathrm{X}$ & $\mathrm{X}$ & $\mathrm{X}$ & $\mathrm{X}$ & $\mathrm{X}$ \\
\hline Klebsiella ozaenae & & & & & $\mathrm{X}$ & \\
\hline Klebsiella oxytoca & & & & & $\mathrm{X}$ & \\
\hline Klebsiella pneumo ss pneumoniae & & & & & $\mathrm{X}$ & \\
\hline Pantoea agglomerans & & & & $X$ & $X$ & $\mathrm{X}$ \\
\hline \multicolumn{7}{|l|}{ Environmental Bacteria } \\
\hline Acinetobacter baumannii & & & & & $\mathrm{X}$ & \\
\hline Acinetobacter lwoffi & & & $\mathrm{X}$ & & $\mathrm{X}$ & \\
\hline Aeromonas caviae & & & & $\mathrm{X}$ & $\mathrm{X}$ & $\mathrm{X}$ \\
\hline Aeromonas hydrophilia & & $\mathrm{X}$ & & & $\mathrm{X}$ & $\mathrm{X}$ \\
\hline Aeromonas sp. & & & & & & $\mathrm{X}$ \\
\hline Aeromonas sobria & & & & & & $\mathrm{X}$ \\
\hline Bacillus sp. 1 & & & & & & $\mathrm{X}$ \\
\hline Bacillus sp. 2 & & $\mathrm{X}$ & $\mathrm{X}$ & & & $\mathrm{X}$ \\
\hline Brevundimonas diminuta & & & & & $\mathrm{X}$ & \\
\hline Chromobacterium $s p$. & & & & & & $\mathrm{X}$ \\
\hline Chryseobacterium meningosepticum & & & $\mathrm{X}$ & & & \\
\hline Comamonas testosterone & & & & & $\mathrm{X}$ & \\
\hline Empedobacter brevis & & & $\mathrm{X}$ & & & \\
\hline Hafnia alvei & $\mathrm{X}$ & & & & $X$ & \\
\hline Kluyvera cryocrescens & & & & $\mathrm{X}$ & & \\
\hline Listonella (Vibrio) anguillarum & & & & $\mathrm{X}$ & $\mathrm{X}$ & \\
\hline Micrococcus sp. & & & $\mathrm{X}$ & & & \\
\hline Moraxella osloensis & $\mathrm{X}$ & & & & & \\
\hline Myroides odoratum & & & $\mathrm{X}$ & & & \\
\hline Ochrobactrum anthropi & $\mathrm{X}$ & & & & & \\
\hline Proteus mirabilis & & & $\mathrm{X}$ & & & \\
\hline Pseudomonas aeruginosa & & & & $\mathrm{X}$ & & \\
\hline Pseudomonas aeruginosalputida & & & & $\mathrm{X}$ & & \\
\hline Pseudomonas alcaligenes & $\mathrm{X}$ & $\mathrm{X}$ & $\mathrm{X}$ & $\mathrm{X}$ & $\mathrm{X}$ & \\
\hline Pseudomonas flourescens & & $\mathrm{X}$ & $X$ & & $X$ & $\mathrm{X}$ \\
\hline Pseudomonas flourescens/putida & & $\mathrm{X}$ & $\mathrm{X}$ & & & $\mathrm{X}$ \\
\hline Pseudomonas mendocina & & & $\mathrm{X}$ & & & $\mathrm{X}$ \\
\hline Pseudomonas pseudoalcaligenes & & & & & & $\mathrm{X}$ \\
\hline Pseudomonas stutzeri & & $\mathrm{X}$ & & & $\mathrm{X}$ & $\mathrm{X}$ \\
\hline Pseudomonas sp. & & & $\mathrm{X}$ & $\mathrm{X}$ & $\mathrm{X}$ & $\mathrm{X}$ \\
\hline Psychrobacter phenylpyruvica & & $X$ & & & & \\
\hline Serratia fonticola & & & & & & $\mathrm{X}$ \\
\hline Serratia marcescens & & & & & $\mathrm{X}$ & \\
\hline Serratia plymuthica & & & & & $\mathrm{X}$ & \\
\hline Serratia proteamaculans & & & & & $\mathrm{X}$ & \\
\hline Shewanella putrefaciens & & & & & & $\mathrm{X}$ \\
\hline Sphingomonas paucimobilis & & & & & & $\mathrm{X}$ \\
\hline Stentrophomonas maltophilia & & & & & $\mathrm{X}$ & \\
\hline Vibrio alginolyticus & $X$ & & & & & \\
\hline Vibrio fluvialis & $\mathrm{X}$ & & & & & \\
\hline
\end{tabular}




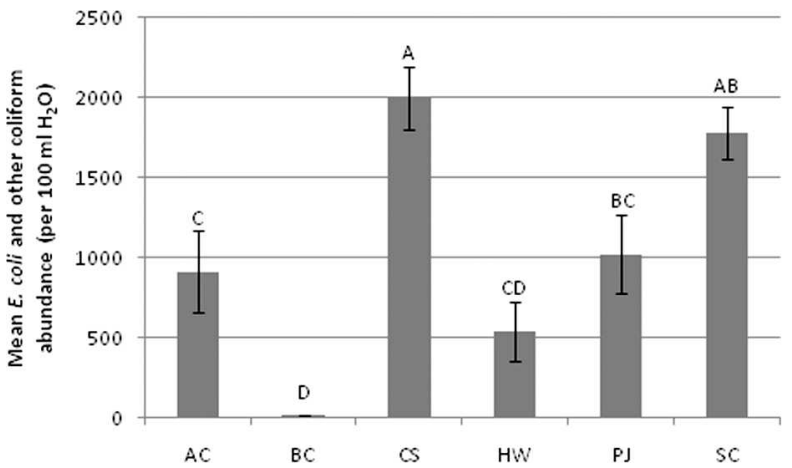

Figure 2. Mean total abundance $(+l-\mathrm{SE}$ ) (per $100 \mathrm{ml}$ of $\mathrm{H}_{2} \mathrm{O}$ ) of $E$. coli and other coliform from six caves located in north Alabama and northwest Georgia. Columns with the same letter(s) are not significantly different at $P \leq \mathbf{0 . 0 5}$ according to Tukey's multiple comparison procedure. $\mathrm{AC}=$ Anvil Cave, $\mathrm{BC}=$ Byers Cave, $\mathbf{C S}=$ Cave Springs Cave, HW=Howard's Waterfall Cave, PJ=Pettyjohns Cave, $\mathrm{SC}=$ Sauta Cave.

distance zones, and the intermediate zone was significantly higher in coliforms than the deep zone. We collected eleven species of bacteria from Anvil Cave (Table 1), seven of which were isolated from the entrance zone. Two Vibrio species ( $V$. alginolyticus and $V$. fluvialis) were isolated from Anvil Cave. They are common in estuarine and marine environments (Roberts et al., 1982), but can be causative agents of diseases in humans (West, 1989).

\section{Byers CAVE}

Although not significantly different, E. coli and other coliforms were higher in abundance in the deep zone compared to the entrance zone (Table 2). Only eight bacteria species were isolated from Byers (Table 1) and, overall, E. coli and other coliforms were found in very low abundance compared to all other caves.

\section{Cave Springs Cave}

E. coli and other coliform abundance were significantly higher in the deep zone compared to the entrance zone (Table 2). Thirteen species of bacteria were isolated from Cave Springs Cave (Table 1). Within the intermediate zone, a Bipolaris spp. (dematiaceous fungus) was isolated, several species of which are considered to be a potential human pathogens.

\section{Howard's Waterfall Cave}

E. coli and other coliforms were higher in abundance in the entrance zone compared to the deep zone, but the difference was not significant (Table 2). We collected ten species of bacteria from Howard's Waterfall Cave (Table 1). Despite low abundance of coliforms within the deep zone, seven species of bacteria were isolated there, including Listonella (Vibrio) anguillarum. L. anguillarum is primarily isolated from marine environments, but has on occasion been isolated from freshwater environments (Chen et al., 2006). It causes fish disease worldwide (Powell and Loutit, 1994).

\section{Pettyjohns Cave}

E. coli and other bacteria were found throughout our sampling transect. No significant differences in abundance were noted between the entrance and deep zone (Table 2). We collected twenty-four species of bacteria from Pettyjohns Cave (Table 1). Listonella (Vibrio) anguillarum was also isolated from the entrance zone of this cave.

\section{Sauta Cave}

E. coli and other coliform bacteria were not significantly different among the distance zones (Table 2). However, E. coli abundance did increase at deeper distance intervals. Nineteen species were collected within Sauta Cave (Table 1). One species collected, Shewanella putrefaciens, is a common environmental isolate that composes biofilms (McLeod et al., 2002) and can use multiple electron acceptors (including manganese) for aerobic respiration (Myers and Myers, 2001), which may allow for its survival in cave ecosystems.

\section{DisCUSSION}

A great deal of heterogeneity existed among caves, such as location and separation of water pools. Although distance from an entrance is a variable that can influence bacterial abundance (as observed in Anvil Cave), other variables appear to be more important in controlling abundance and species richness of coliform bacteria in cave ecosystems. Outside influences, such as number of human and bat visitors and watershed differences, differed among caves, which probably accounted for the lack of correlation between $E$. coli and other bacteria abundances and species richness and distance from an entrance. Abundance levels of E.coli and other coliform bacteria fluctuated widely among water pools in the same distance zone of some caves, suggesting that isolated pools are not necessarily influenced by other nearby pools, and bacterial presence may depend more heavily on a direct source such as human or animal visitors rather than an indirect source such as watershed contamination.

The isolation of many potentially pathogenic bacteria from these cave waters suggests that these species are able to remain viable in a low metabolic state. E. coli has been shown to survive longer in soil kept at low temperatures (Teague et al., 1995), and Flint (1987) found E. coli surviving for extended periods of time in cold river water. Some of these coliforms and environmentals may be adhering to biofilms on the substrate, which could help sustain the species in cave environments. Epilithic biofilms have been shown to be an important energy source for aquatic cave communities (Simon et al., 2003). Biofilms 
ESCHERICHIA COLI, OTHER COLIFORM, AND ENVIRONMENTAL CHEMOHETEROTROPHIC BACTERIA IN ISOLATED WATER POOLS FROM SIX CAVES IN northern Alabama And northwestern Georgia

Table 2. Mean E. coli and other coliform abundance (+I-SE) (per $\left.100 \mathrm{ml} \mathrm{H}_{2} \mathrm{O}\right)$ from each cave and the various distance zones within each cave.

\begin{tabular}{lccc}
\hline Cave & Entrance Zone & Intermediate Zone & Deep Zone \\
\hline Anvil Cave & $2419.6(0)^{\mathrm{a}}$ & $1035.8(564.5)^{\mathrm{b}}$ & $100.68(52.3)^{\mathrm{c}}$ \\
Byers Cave & $6.76(3.1)^{\mathrm{a}}$ & $\mathrm{NP}$ & $23.87(7.8)^{\mathrm{a}}$ \\
Cave Springs Cave & $1065.5(553.1)^{\mathrm{a}}$ & $2099(320.7)^{\mathrm{ab}}$ & $2419.6(0)^{\mathrm{b}}$ \\
Howard's Waterfall Cave & $823.86(352.5)^{\mathrm{a}}$ & $\mathrm{NP}$ & $253.3(68.8)^{\mathrm{a}}$ \\
Pettyjohns Cave & $1108.6(336.3)^{\mathrm{a}}$ & $\mathrm{NP}$ & $939.25(361.8)^{\mathrm{a}}$ \\
Sauta Cave & $1758.5(298.9)^{\mathrm{a}}$ & $1813(173.3)^{\mathrm{a}}$ & $1780.5(288.4)^{\mathrm{a}}$ \\
\hline
\end{tabular}

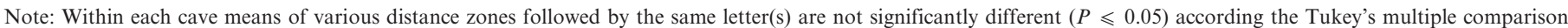
procedure

NP $=$ No pools present

Lower case letters indicate which caves have differences in bacterial abundance among the three zones.

can also trap nutrients (Costerton and Lappin-Scott, 1989), which can increase the survival of non-endemic bacteria (Boyle et al., 1991).

Although our cultivation techniques favored cultivation of coliform bacteria, we also isolated forty environmental chemoheterotrophic bacterial species. Our study highly underestimated environmental bacteria, because our cultivation techniques targeted coliform bacteria, and our result is not representative of the true bacterial species diversity. Many cave bacteria species may have been inhibited by our media or inoculation temperature, which do not mimic a cave environment. According to McNamara and Mitchell (2005), less than $10 \%$ of bacteria $(<1 \%$ in many instances) from an environmental sample can be cultivated by standard laboratory techniques.

Each cave illustrated unique physical differences that may help explain differences in abundance and species of bacteria. Anvil Cave, a maze cave, has over $20 \mathrm{~km}$ (13 miles) of passages and several entrances and receives few human visitors. Most human visitors and other animals will necessarily pass through an entrance zone, but they may become dispersed in the mazes beyond these zones, which could account for the higher E. coli and other coliform abundances and species richness within the first distance zone. Anvil Cave is, however, located primarily underneath pasture land that could be a source of bacteria.

Byers Cave, which is one of Georgia's largest caves, contains over $8 \mathrm{~km}$ (5 miles) of passages and contains a waterfall, and many pools are present within the deep zone, here $>400 \mathrm{~m}$ from the entrance. Byers Cave is not heavily trafficked by humans, and water seepage from the general watershed is a probable source for the bacteria in these distance zones. Byers Cave is located within a pristine wooded area that is far from any human development, which could account for the overall low abundance and species richness of bacteria.

Cave Springs and Sauta Caves both have large openings and contain streams roughly 3 to 5 meters wide that slowly drain towards the entrance. Large colonies of endangered gray bats (Myotis grisescens) inhabit Cave Springs and Sauta Caves, with maternity colonies formed during spring and summer. These caves are closed to the public and get only an occasional human visitor. Total organic matter in soil has been shown to increase in areas with larger numbers of bats in Cave Springs and Sauta Caves (Joshua Campbell et al., unpubl. data), which probably accounted for the high abundance of $E$. coli and other coliforms.

Howard's Waterfall Cave is a horizontal cave that is over $3 \mathrm{~km}$ long ( 2 miles long) and receives approximately 1000 human visitors per year, with most only exploring the first part of the cave, which could account for the increased abundance of $E$. coli and other coliforms within the entrance zone. However, watershed sources and other animals are also possible sources for the increased abundance of $E$. coli and other coliforms from the entrance zone. The higher number of species isolated from the deep zone (including Listonella (Vibrio) anguillarum) is an interesting result and may suggest a watershed source of bacteria, even though overall coliform and other bacteria abundance was low in this zone.

Pettyjohns Cave has over $10.5 \mathrm{~km}$ (6.5 miles) of passages and is a popular cave that draws approximately 10,000 visitors per year (Padgett, 1999). The majority of human visitors only explore near the entrance, which could explain the high numbers of bacteria within the entrance zone. In one area 300 to 325 meters in, a spike in E. coli and other coliforms was observed. Here the cave narrows, which forces any cavers to pass through any pools present, suggesting that the high number of human visitors could be a culprit in these spikes. Although the high number of species is likely due to the high number of people that visit this cave, watershed sources and other animals could also be contributing factors. Neither Howard's Waterfall nor Pettyjohns Caves contain fish, which suggests Listonella (Vibrio) anguillarum entered from the watershed through the aquifer, rather than by way of possibly diseased fish.

\section{Conclusions}

Due to the heterogeneity of these caves, general patterns can be difficult to discern. However, bacterial abundance and species richness in caves can be influenced by humans, 
other animals such as bats, and watershed uses. Cave bacteria can be used as bioindicators of water quality, and high abundance could be an ecosystem warning signal. High levels of bacteria abundance, especially coliforms, could also be a human health concern. Humans could come into direct contact with contaminated pools by caving and indirectly through water wells. Overall, we found widespread fecal contamination in all caves, and people with scrapes or cuts should use caution while caving. Drinking directly from pools without filtration should be avoided at all times. Many organisms that live in caves are very sensitive to ecosystem disturbances and may have limited populations and slow reproduction times. How increases in non-native bacterial species affect cave macroinvertebrates and other animals should be investigated.

\section{ACKNOWLEDGMENTS}

We graciously acknowledge the IDEXX Corporation, especially Patsy Root, for donating the coliform testing supplies. We also thank Dwight Cooley and Bill Gates from the U.S. Fish and Wildlife Service for giving us permission for sampling Cave Springs and Sauta Caves, and give special thanks to Bill Gates for acting as an intrepid guide. We thank Marty Abercrombie from the Southeastern Cave Conservancy for guiding us through Howard's and Byers Caves and the Georgia DNR for access to Pettyjohns Cave. We thank Bo Chesser for help with GIS work. Finally, we thank cavers Lukas Gonzalez, Jonathan Prouty, and Maghan Woods for assisting with field work. This research was supported by a Shorter College research grant.

\section{REFERENCES}

Boyle, M., Ford, T., Maki, J.S., and Mitchell, R., 1991, Biofilms and the survival of opportunistic pathogens in recycled water: Waste Management and Research, v. 9, p. 465-470, doi: 10.1177/ $0734242 X 9100900165$.

Caumartin, V., 1963, Review of the microbiology of underground environments: Bulletin of the National Speleological Society, v. 25, p. $1-14$.

Chen, C.Y., Chao, C.B., and Bowser, P.R., 2006, Infection of tilapia Oreochromis sp. by Vibrio vulnificus in fresh water and low-salinity environments: Journal of the World Aquaculture Society, v. 37, p. 82-88, doi: 10.1111/j.1749-7345.2006.00010.x.

Clesceri, L.S., Greenberg, A.E., and Eaton, A.D., eds., 1998, Standard Methods for the Examination of Water and Wastewater, 20th ed., APHA, Washington, D.C., 1325 p.

Costerton, J.W., and Lappin-Scott, H.M., 1989, Behavior of bacteria in biofilms: American Society for Microbiology News, v. 55, p. 650-654.

Culver, D.C., 1970, Analysis of simple cave communities I. Cave as islands: Evolution, v. 24, p. 463-474.

Culver, D.C., Deharveng, L., Bedos, A., Lewis, J.J., Madden, M., Reddell, J.R., Sket, B., Trontelj, P., and White, D., 2006, The mid-latitude biodiversity ridge in terrestrial cave fauna: Ecography, v. 29, p. $120-128$, doi: $10.1111 / j .2005 .0906-7590.04435 . x$.

Davis, R.K., Hamilton, S., and Van Brahana, J., 2005, Escherichia coli survival in mantled karst springs and streams, northwest Arkansas Ozarks, USA: Journal of the American Water Resources Association, v. 41, p. 1279-1287, doi: 10.1111/j.752-1688.2005.tb03800.x.
Flint, K.P., 1987, The long-term survival of Escherichia coli in river water: Journal of Applied Bacteriology, v. 63, p. 261-270, doi: 10.1111/ j.1365-2672.1987.tb04945.x.

Graening, G.O., and Brown, A.V., 2003, Ecosystem dynamics and pollution effects in an Ozark cave stream: Journal of the American Water Resources Association, v. 39, p. 1497-1507, doi: 10.1111/ j.1752-1688.2003.tb04434.x.

Green, W., Ellicott, L., and Crawford, N., 1990, Investigation of nonpoint source pollution associated with karst aquifer systems: Transactions of the Kentucky Academy of Science, v. 51, p. 177-181.

Groth, I., and Saiz-Jimenez, C., 1999, Actinomycetes in hypogean environments: Geomicrobiology Journal, v. 16, p. 1-8.

Hunter, A.J., Northup, D.E., Dahm, C.N., and Boston, P.J., 2004, Persistent coliform contamination in Lechuguilla cave pools: Journal of Cave and Karst Studies, v. 66, p. 102-110.

Kelly, W.R., Panno, S.V., Hackley, K.C., Martinsek, A.T., Krapac, I.G., Weibel, C.P., and Storment, E.C., 2009, Bacteria contamination of groundwater in a mixed land-use karst region: Water Quality Exposure and Health, v. 1, p. 69-78, doi: 10.1007/s12403-009-0006-7.

Laiz, L., Groth, I., Schumann, P., Zezza, F., Felske, A., Hermosin, B., and Saiz-Jimenez, C., 2000, Microbiology of the stalactites from Grotta dei Cervi, Porto Badisco, Italy: International Microbiology, v. 3, p. $25-30$.

Lerch, R.N., Erickson, J.M., and Wicks, C.M., 2001, Intensive water quality monitoring in two karst watersheds of Boone County, Missouri, in Rea, G.T., ed., Proceedings of the 2001 National Cave and Karst Management Symposium, Tucson, Arizona, Oct. 16-19, 2001, Tucson, Coronado National Forest, p. 151-168.

McLeod, E.S., MacDonald, R., and Brözel, V.S., 2002, Distribution of Shewanella putrefaciens and Desulfovibrio vulgaris in sulphidogenic biofilms of industial cooling water system determined by fluorescent in situ hybridization: Water SA, v. 28, p. 123-128.

McNamara, C.J., and Mitchell, R., 2005, Microbial deterioration of historic stone: Frontiers in Ecology and the Environment, v. 3, p. 445-451, doi: 10.1890/1540-9295(2005)003[0445:MDOHS]2.0.CO;2.

Moore, G.W., and Sullivan, G.N., 1997, Speleology: Caves and the Cave Environment, third edition: St. Louis, Cave Books, 176 p.

Myers, J.M., and Myers, C.R., 2001, Role for outer membrane cytochromes OmcA and OmcB of Shewanella putrefaciens MR-1 in reduction of manganese dioxide: Applied and Environmental Microbiology, v. 67, p. 260-269, doi: 10.1128/AEM.67.1.260-269.2001.

Northup, D.E., Beck, K.M., and Mallory, L.M., 1997, Human impact on the microbial communities of Lechuguilla cave: Is protection possible during active exploration?, abs., National Speleology Society Convention Program, Sullivan, Missouri, $55 \mathrm{p}$

Northup, D.E., and Lavoie, K.H., 2001, Geomicrobiology of caves: A review: Geomicrobiology Journal, v. 18, p. 199-222, doi:10.1080/ 01490450152467750

Olstadt, J., Schauer, J.J., Standridge, J., and Kluender, S., 2007, A comparison of ten USEPA approved total coliform/E. coli tests: Journal of Water and Health, v. 5, p. 267-282, doi: 10.2166/ wh.2007.008

Padgett, A., 1999, Pigeon Mountain: Thirty years of noninterference, in Rea, G.T., ed., Proceedings of the 1999 National Cave and Karst Management Symposium, Chatanooga, Tennessee, Southeastern Cave Conservancy, p. 143-147.

Peck, S.B., 1976, The effect of cave entrances on the distribution of caveinhabiting terrestrial arthropods: International Journal of Speleology, v. 8, p. 309-321.

Poulson, T.L., and White, W.B., 1969, The cave environment: Science, v. 165 , p. $971-981$

Powell, J.L., and Loutit, M.W., 1994, The detection of fish pathogen Vibrio anquillarum in water and fish using a species-specific DNA probe combined with membrane filtration: Microbial Ecology, v. 28, p. 375-383, doi:10.1007/BF00662030.

Roberts, N.C., Siebeling, R.J., Kaper, J.B., and Bradford, Jr., H.B., 1982, Vibrios in the Louisiana coast environment: Microbial Ecology, v. 8, p. 299-312, doi: 10.1007/BF02010670.

Simon, K.S., Benfield, E.F., and Macko, S.A., 2003, Food web structure and the role of epilithic biofilms in cave streams: Ecology, v. 84, p. 2395-2406.

Taylor, S.J., Krejca, J.K., and Denight, M.L., 2005, Foraging range and habitat use of Ceuthophilus secretus (Orthoptera: Rhaphidophoridae), 
ESCHERICHIA COLI, OTHER COLIFORM, AND ENVIRONMENTAL CHEMOHETEROTROPHIC BACTERIA IN ISOLATED WATER POOLS FROM SIX CAVES IN NORTHern Alabama And northwestern Georgia

a key trogloxene in central Texas cave communities: American Midland Naturalist, v. 154, p. 97-114.

Teague, K.A., Wolf, D.C., and Vendrell, P.F., 1995, Survival of fecal contamination indicator organisms in soil: Arkansas Water Resources Center, Publication No. 173, 28 p.

U.S. EPA, 1994, National Primary and Secondary Drinking Water Regulations: Analytical Methods for Regulated Drinking Water Contaminants: Federal Register, 5 December 1994, 40 Code of Federal Regulations parts 141, $143 \mathrm{p}$.

U.S. EPA, 1997, Manual for the Certification of Laboratories Analyzing Drinking Water: Criteria and Procedures, Quality Assurance, fourth edition: Environmental Protection Agency document 815-B-97-001, $186 \mathrm{p}$.

U.S. EPA, 1999, National Primary and Secondary Drinking Water Regulations: Analytical Methods for Chemical and Microbiological Contaminants and Revisions to Laboratory Certification Requirements: Final Rule: Federal Register, 1 December 1999, p. 67449-67467, 40 Code of Federal Regulations parts 141, $143 \mathrm{p}$.

West, P.A., 1989, The human pathogenic vibrios - A public health update with environmental perspectives: Epidemiology and Infection, v. 103, p. 1-34, doi: 10.1017/S0950268800030326. 